\title{
Bioecology of Sargassum sp. and its Extract Bioactivity as Anti-MDR Bacteria
}

\author{
Rini Pramesti ${ }^{1 *}$, Wilis Ari Setyati ${ }^{1}$, Muhammad Zainuddin²${ }^{2}$, and Maya Puspita ${ }^{3}$ \\ ${ }^{1}$ Department Marine Science, Diponegoro University \\ J. Prof. H. Soedarto, S.H, Tembalang, Semarang, Central Java 50275 Indonesia \\ ${ }^{2}$ Aquaculture Department, Nahdlatul Ulama Islamic University \\ Jl. Taman Siswa, Pekeng, Tahunan, Jepara, Central Java 59427 Indonesia \\ 3University of South Brittany \\ EA 3884. LBCM. IUEM. F-56000 Vannes, France \\ Email: rinipramesti63@gmail.com
}

\begin{abstract}
This study was done to investigate the bioecology and extract bioactivity of Sargassum sp from Jepara district. Seaweed was collected from Teluk Awur, Panjang Island, Bandengan, Ujung Piring and Bondo. There were seven species of Sargassum identified i.e. S. duplicatum, S. polycystum, S. echinocarpum, S. cinerium, S. crassifolium, S. plagyophillum and S. binderi. Community structure indices were calculated based on data collected by survey. Antibacterial activity of Sargassum extract was done on MDR bacteria. The results showed that diversity index at Panjang Island, Bandengan, and Ujung Piring were categorized as medium, while Teluk Awur and Bondo were categorized as low. Evenness index was high at Teluk Awur, Panjang Island, Bandengan and Ujung Piring and Bondo was low. There was no dominant species found in most of the locations. The principal component analysis exhibited the main variable that affected the Sargassum at Teluk Awur was phosphate, Panjang Island was depth, Ujung Piring was salinity and Bondo was temperature, dissolved oxygen and $\mathrm{pH}$, respectively. There was character similarity between Panjang Island and Bandengan (99.73\%), meanwhile, at Teluk Awur, Ujung Piring, and Bondo, the similarity was 99.62\%, 99.60\%, and 99.52\%, respectively. Antibacterial activity of Sargassum sp. demonstrated a positive activity against the MDR bacteria, Staphylococcus aureus $(6.28 \pm 0.04 \mathrm{~mm})$, Escherichia coli $(6.96 \pm 0.19 \mathrm{~mm})$, and $\mathrm{S}$. epidermidis $(12.65 \pm 0.23 \mathrm{~mm})$. Clustering analysis of extracts with bactericidal characteristic found three classes with similarity of class 1, 2 and 3 at 72.33\%, 76.80\% and 58.50\%, respectively. Sargassum sp. was categorized in class 1 had the best antibacterial activity and the highest abundance value.
\end{abstract}

Keywords: ecology, community, Sargassum sp., extracts, antibacterial

\section{Introduction}

Research on seaweed, Sargassum sp., has been conducted quite extensively but information that explains about environment towards distribution, diversity, and bioactive abundance from Sargassum sp. is limited. Sargassum sp. has been reported to show promising pharmacological properties serving as antiviral (Hardouin et al., 2013), antitumor (Nianjun et al., 2004), antioxidant (Rastian et al., 2007; Bhaigyabati, 2011; Zaragoza et al., 2008; Khaled et al., 2012; Tanniou et al., 2013), antifouling (Plouguerne et al., 2010), and antifungal (Manivannan, 2011; Khaled et al., 2012). S. fulvellum and S. thunbergii showed antiphyretic, analgesic, and anti-inflammatory activities in mice (Kang et al., 2008). S. echinocarpum, S. duplicatum and S. polycystum performed potential antioxidant (Widowati et al., 2014). S. aquifolium, S. ilicifolium and S. polycystum showed antibacterial activity against Bacillus subtilis, Pseudomonas aeruginosa and Escherichia coli (Puspita et al., 2012). S. pallidum can serve as antioxidant and antihemolysis agents exhibiting potential for further exploration as functional food or complementary medicine (Bhaigyabati et al., 2011; Li et al., 2017). S. tenerrimum from India is reported to have antibacterial activity against Klebsiella pneumonia, Escherichia coli, Staphylococcus aureus, Proteus sp., Streptococcus sp., Pseudomonas aeruginosa, Salmonella sp., Shewanella sp., Vibrio fluvialis, V. splendidus, V. cholera, V. parahaemolyticus, Shigella flaxneri, Staphylococcus epidermidis, Aeromonas liquefaciens and Bacillus subtilus. Furthermore, Sargassum sp. also have antifungal activity against Aspergillus niger, A. flavus, A stetreus, Candida albicans and Penicillum sp. (Manivannan et al., 2011).

The above research focuses only on the perspective of active compounds, but which relates to ecological factors is very limited. This study was 
conducted to see the bioactive compounds from Sargassum sp. and its relation to ecological conditions in Jepara. This is considering that the area is one of the locations that have seaweed resources in Indonesia. One of the most abundant seaweed is Sargassum sp.

Exploration of Sargassum sp. especially about the use of active compounds is necessary in order to be utilized. In addition, information about the relationship between Sargassum sp. and the environment in producing secondary metabolites can provide direction to the sustainable management of these marine resources.

\section{Materials and Methods}

\section{Observation of Sargassum sp.}

Sargassum were collected from 5 locations in Jepara, i.e. Teluk Awur, Panjang Island, Bandengan, Ujung Piring and Bondo. Observation of Sargassum $\mathrm{sp}$. was conducted by $100 \mathrm{~m}$ line transect (English et al., 1997). Environmental parameters observed were temperature, brightness, depth, salinity, $\mathrm{pH}$, DO and current velocity. A whole thallus of seaweed was taken for taxonomic identification based on morphology study. Collected seaweeds were rinsed with tap water to remove the epiphytes and remaining debris. Prior to natural drying under the shade, seaweeds were cut to pieces $( \pm 5 \mathrm{~cm})$. Further, the dried seaweeds were ground by means of with multiuse blender to obtain powder material (Manivannan et al., 2011).

\section{Extraction of Sargassum sp.}

Twenty five grams of dry seaweed was extracted gradually by using $100 \mathrm{~mL} n$-hexane, ethyl acetate, and methanol. The extraction was performed for 24 hours in room temperature. The extracted seaweed was filtered though Whatman filter paper. The remaining residues of seaweed were re-extracted applying the same process and solvents. Filtrates obtained from the extraction process were pooled. $\mathrm{N}$-hexane, ethyl acetate and methanol filtrates were evaporated to dryness with vacuum rotary evaporator at $40^{\circ} \mathrm{C}$ in $500 \mathrm{mmHg}$. $\mathrm{N}$ hexane, ethyl acetate and methanol extracts of Sargassum sp. were dried using $\mathrm{N}_{2}$ prior to storage in $-20^{\circ} \mathrm{C}$ (Kanjana et al., 2011).

\section{Antibacterial activity test}

Antibacterial activity test used agar diffusion method with Zobell media (peptone, yeast, and bacto agar). Antibacterial test used 3 isolates of MDR candidates, i.e Staphylococcous aureus, Esherichia coli, and S. epidermidis.
Bacteria culture was centrifuged at $5000 \mathrm{rpm}$ for 10 minutes then dissolved with PBS and measured using Optical Density Spectrophotometer $\lambda 600 \mathrm{~nm}$ between 0.6-0.8 (Lalitha, 2004) then pipetted for $0.1 \mathrm{~mL}$ and inoculated to the surface of media petri, after that it was incubated for 30 minutes. Antibacterial test using extract solution and antibiotic chloramphenicol as the control (+) for with concentration of $2500 \mathrm{ppm}$ and in each paper disc sterile was given extract solution for $20 \mu \mathrm{l}$ (50

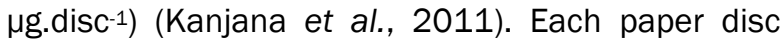
was placed in petri dish with agar and bacteria then being storage in the incubator with the temperature of $37^{\circ} \mathrm{C}$ for $24-48 \mathrm{~h}$ (Pelczar et al., 2005).

\section{Data analysis}

The abundance value was used to describe the community structure of Sargassum which includes Diversity Index ( $\left.\mathrm{H}^{\prime}\right)$, Evenness Index (e) and Dominancy Index (C). Multivariable statistic approach was used to analyze physical-chemical water parameters. This analysis aimed to see the linkages of physical-chemical variables towards observation stations based on the approach of analysis to the main components (OCA).

\section{Results and Discussion}

This study found 3 species of Sargassum in Teluk Awur, 4 species in Panjang Island, 3 species in Bandengan, 3 species in Ujung Piring, and 1 species in Bondo. Highest total abundance was found in Bondo for 1510 ind.200m-2. Highest Diversity Index $\left(\mathrm{H}^{\prime}\right)$ was in Panjang Island (1.24), Bandengan and Ujung Piring (1.09- moderate), Teluk Awur (1.00 low) and Bondo (0.00 - low).

The value of Evenness Index was similar and categorized as high at all locations except Bondo, i.e. Teluk Awur (0.91), Panjang Island (0.90), Bandengan $(0.99 \mathrm{~h})$, and Ujung Piring (0.99) which shows that the environmental is stable. While in Bondo was low (0.00) and shows that environment is under pressured and unstable. It is probably caused by the existence of PLTU (Steam Electricity Power Plant) activity. There is no species domination in Teluk Awur, Panjang Island and Bandengan. S. binderi dominates Bondo area, probably due to highest current velocity than the other stations. Current has a role to clean up the dirt attached so that the nutrient can go to the entire surface of thallus body through diffusion osmosis process.

Result of principle component analysis $\left(\mathrm{F}_{1} \mathrm{xF}_{2}\right)$ shows, the main component of variables of water quality in Teluk Awur was phosphate. It is assumed that in the land area of that station there is an agricultural activity that flows solved phosphate 
waste and carried to observation station. Panjang Island with the depth because this location is a land that separated from the mainland. Ujung Piring with salinity, it is assumed because the beach is sloping/calm and enclosed by the bay so the evaporation process is high. Salinity at Ujung Piring is assumed low/high. It is because of the beach sloping/calm and enclosed by the bay, thus evaporation process is high. Bondo with temperature, $\mathrm{DO}$ and $\mathrm{pH}$, it is assumed because of outcome from waste of PLTU activity result and it causes high temperature and increasing condition of $\mathrm{DO}$ and $\mathrm{pH}$, meanwhile Bandengan has no main component (Figure 1). Result of correlation Pearson test of water quality towards the abundance shows, each station has different amount and variable composition which influenced to the abundance distribution. Teluk Awur has 8 variables; Panjang

Tabel 1. The Abundance Value (ind.200m-2), Diversity Index (H'), Evenness Index (e), Dominancy Index (C) and The Average Value of Water Parameters

\begin{tabular}{|c|c|c|c|c|c|}
\hline \multirow{2}{*}{ Species } & \multicolumn{5}{|c|}{ Station } \\
\hline & Teluk Awur & Panjang Island & Bandengan & Ujung Piring & Bondo \\
\hline S. duplicatum & 504 & 147 & 0 & 256 & 0 \\
\hline S. polycystum & 159 & 142 & 0 & 299 & 0 \\
\hline S. echinocarpum & 437 & 0 & 258 & 0 & 0 \\
\hline S. cinereum & 0 & 75 & 329 & 0 & 0 \\
\hline S. crassifolium & 0 & 337 & 0 & 0 & 0 \\
\hline S. plagyophyllum & 0 & 0 & 222 & 0 & 0 \\
\hline S. binderi & 0 & 0 & 0 & 368 & 1510 \\
\hline Total Abundance (ind.200 m-2) & 1100 & 701 & 809 & 923 & 1510 \\
\hline Total Species & 3 & 4 & 3 & 3 & 1 \\
\hline \multirow{2}{*}{ Diversity Index (H') } & 1 & 1,24 & 1,09 & 1,09 & 0 \\
\hline & Low & Medium & Medium & Medium & Low \\
\hline \multirow{2}{*}{ Index of Evenness (e) } & 0.91 & 0.90 & 0.99 & 0.99 & 0 \\
\hline & High & High & High & High & Low \\
\hline \multirow{2}{*}{ Dominancy Index (C) } & 0.39 & 0.33 & 0.34 & 0.34 & 1 \\
\hline & - & - & - & - & + \\
\hline Depth (m) & 1.2 & 3.9 & 2.8 & 0.9 & 3.6 \\
\hline Visibility (m) & 1.2 & 2.3 & 2.1 & 0.8 & 1.5 \\
\hline DO & 4.1 & 5.6 & 5.8 & 5.4 & 5.8 \\
\hline $\mathrm{pH}$ & 7.2 & 7.2 & 7.2 & 7.2 & 7.3 \\
\hline Temperature $\left({ }^{\circ} \mathrm{C}\right)$ & 31 & 31 & 30 & 30 & 32 \\
\hline Salinity $(\% \circ)$ & 32 & 31 & 31 & 32 & 31 \\
\hline Current (m.minute ${ }^{-1}$ ) & 6.0 & 5.8 & 8.1 & 1.2 & 8.2 \\
\hline $\mathrm{PO}_{4}(\mathrm{ppm})$ & 0.013 & 0.003 & 0.006 & 0.001 & 0.001 \\
\hline Nitrate (ppm) & $<0.005$ & $<0.005$ & $<0.005$ & $<0.005$ & $<0.005$ \\
\hline
\end{tabular}

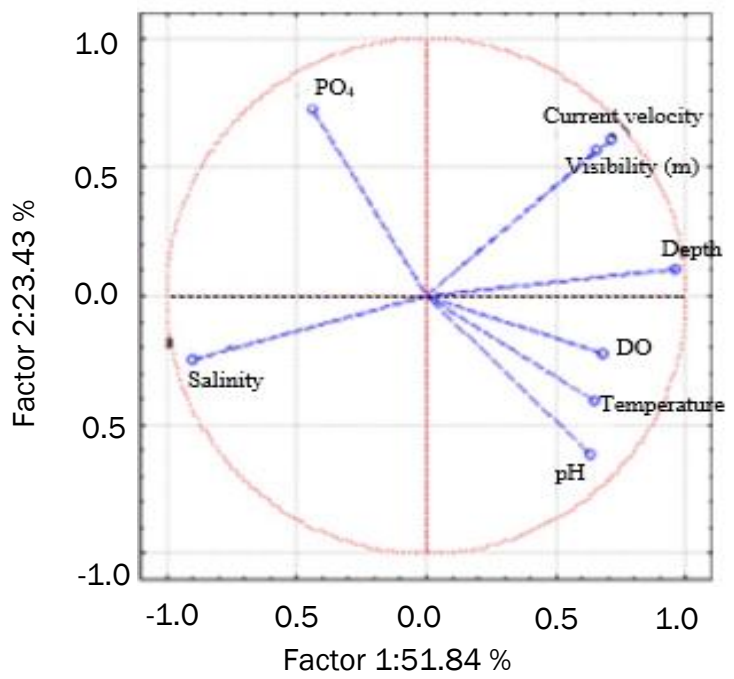

Corelation between variables on the axis 1 and $2\left(F_{1} \times F_{2}\right)$

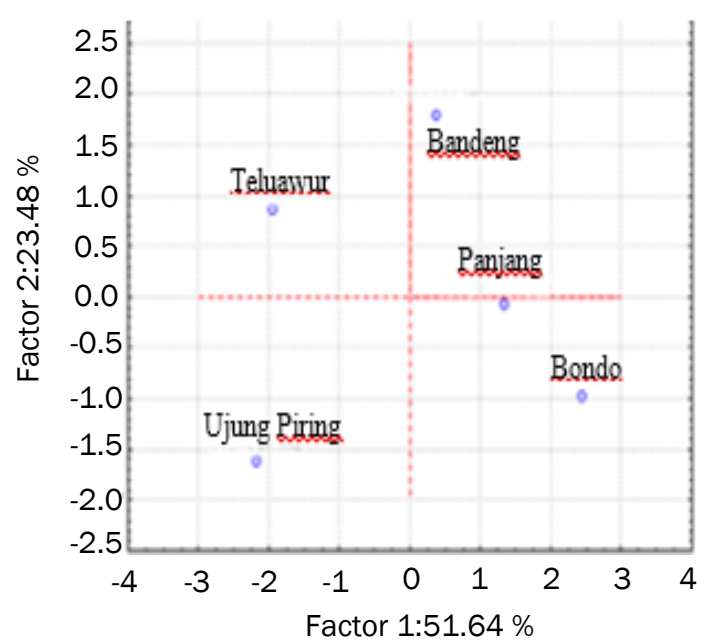

Distribution of observation stations on the axis 1 and $2\left(F_{1} \times F_{2}\right)$

Figure 1. Correlation Between Variables on the Axis 1 and $2\left(F_{1} \times F_{2}\right)$ and Distribution of Observation Stations on the Axis 1 and $2\left(F_{1} \times F_{2}\right)$ 
Island and Bandengan have 7 variables with stable temperature and salinity, Ujung Piring has 4 variables and variable $\mathrm{pH}$, temperature and phosphate tend to be stable. Bondo has 7 variables and stable temperature variable. The result of correlation test shows that there is a variable difference which has positive and negative correlation towards the abundance in each station.

Regression multivariable equation shows the linkage of water parameters towards the distribution of abundance in each station. Analysis result between water qualities towards abundance results the equation that has same component, which is phosphate. The component in Teluk Awur is $\mathrm{pH}(+)$ and Phosphate (-) which function as antagonist in influencing the abundance. It shows, that higher $\mathrm{pH}$ value until certain limits causes increase in distribution of Sargassum abundance in Teluk Awur, in the contrary, higher phosphate results the decrease in abundance distribution.

Regression multivariable equation of water quality characteristics towards abundance, components in Panjang Island are Current (-) and Phosphate $(+)$. It has a function as antagonists in influencing the abundance. It shows that the higher value of current causes the decrease of Sargassum distribution, while the higher value of phosphate will increase in distribution of its abundance.

Components in Bandengan are Depth $(+)$ and Phosphate (-) that function as antagonist in influencing the abundance. It shows that deeper water causes the more abundant the distribution of Sargassum abundance, while higher Phosphate value will decrease the distribution of its abundance. Components in Ujung Piring are Current (-) and Phosphate $(+)$ that function as synergy in pressing the abundance. It shows that stronger current higher value of phosphate, so distribution of Sargassum abundance decreases. Components in Bondo are DO (+) and Current (+) that function as synergy in the increasing of abundance. It shows that higher DO and current increase distribution of Sargassum.

Phosphates in Teluk Awur, Bandengan and Ujung Piring station have negative correlation because the value of phosphate is higher than in Panjang Island. Phosphate is limiting factor which is needed in certain amount for growth. Sargassum needs $\mathrm{P}$ as ion $\mathrm{PO}_{4}$ and this element is known as macro nutrient (Lobban and Harrison, 1997). The content of phosphate that is higher than tolerance limits will cause stunted growth. The current velocity is component in Panjang Island and Ujung Piring. Depth is the component in Bandengan station. Current and depth are hydrodynamic factors that positively and negatively influence Sargassum life.
Depth of water is related to current velocity. In shallow waters, current velocity tends to be bigger than the current velocity in the deeper water. Current can cause tissue damage in Sargassum because of erosion or stirred muddy base substrate resulted in turbidity and inhibit photosynthesis process.

The component in Teluk Awur is $\mathrm{pH}$ and in Bondo is DO. $\mathrm{pH}$ and Do are directive factors that have roles to direct biochemistry reaction in water ecosystem. Concentration of $\mathrm{pH}$ influences fertility and life of microorganisms. Acid water tends to cause death. The $\mathrm{pH}$ value in the water is influenced by $\mathrm{CO}_{2}$ concentration which is acid substance. Seaweed and water vegetation absorb $\mathrm{CO}_{2}$ from the water during photosynthesis is going on so that $\mathrm{pH}$ tends to increase in the noon and decrease in the night. The existence of $\mathrm{O}_{2}$ is important for chemicalbiological process in water and $\mathrm{O}_{2}$ is needed in oxidation process for many kinds of water chemical substances (Dahuri et al., 1996; Lobban and Harrison, 1997).

Result of antibacterial activity shows that $S$. aureus is sensitive $(6.28 \pm 0.04 \mathrm{~mm})$ to extract $S$. echinocarpum in ethyl acetate solvent from Bandengan. Bacteria $E$. coli is sensitive $(6.96 \pm 0.19$ $\mathrm{mm}$ ) to extract $S$. echinocarpum in ethyl acetate solvent from Teluk Awur. Bacteria S. epidermidis is sensitive $(12.65 \pm 0.23 \mathrm{~mm})$ towards extract $\mathrm{S}$. binderi in ethyl acetate solvent from Ujung Piring.

Result of cluster analysis shows that there is a similarity (99.73\%) characteristic of water quality in Panjang Island and Bandengan station. It is probably because two stations are closely located compared to the other stations and similarity to Teluk Awur is 99.62\%, Ujung Piring 99.60\% and Bondo $99.52 \%$. Water cluster analysis shows that Panjang Island is like central cluster, if the stations are arranged based on the closest distance to Panjang Island station results in i.e: Bandengan, Teluk Awur, Ujung Piring, and Bondo. The distance has the same value with result of water quality cluster. Beside that terrestrial activities, beach topography and distance of one station to another will influence the differences of station's water quality. Result of cluster analysis of transparent zone diameter extract activity in each station shows that there is a similarity (99.99\%) in Panjang Island station and Bandengan, while in Teluk Awur, Ujung Piring, and Bondo were 99.93\%, 99.75\% and $99.61 \%$, respectively. The similarities of water quality cluster pattern and cluster of transparent zone diameter extract activity shows that there is a linkage between water quality to active compounds produced by Sargassum (Figure 2 and 3). 
ILMU KELAUTAN December 2017 Vol 22(4):185-192

Table 2. Bioactivity Test of Sargassum Extract as MDR Anti-Bacteria

\begin{tabular}{|c|c|c|c|c|c|}
\hline \multicolumn{3}{|c|}{ Code } & \multirow{2}{*}{$\begin{array}{l}\text { Staphylococcus } \\
\text { aureus }\end{array}$} & \multirow[t]{2}{*}{ Escherichia coli } & \multirow{2}{*}{$\begin{array}{l}\text { Staphylococcus } \\
\text { epidermidis }\end{array}$} \\
\hline Station & Species & Solvent & & & \\
\hline \multirow[t]{9}{*}{ Teluk Awur } & S duplicatum & n-hexane & - & - & $4.34 \pm 1.10$ \\
\hline & & Ethyl acetate & $3.62 \pm 0.05$ & $4.22 \pm 1.23$ & $6.81 \pm 1.46$ \\
\hline & & Methanol & $4.35 \pm 0.32$ & $5.87 \pm 0.98$ & $3.84 \pm 1.57$ \\
\hline & S polycystum & n-hexane & - & - & $3.54 \pm 0.72$ \\
\hline & & Ethyl acetate & $5.88 \pm 0.25$ & $5.52 \pm 0.81$ & $6.44 \pm 0.76$ \\
\hline & & Methanol & $1.94 \pm 0.33$ & $2.71 \pm 0.29$ & $2.06 \pm 0.91$ \\
\hline & S echinocarpum & n-hexane & - & - & $4.49 \pm 0.58$ \\
\hline & & Ethyl acetate & $4.92 \pm 0.18$ & $6.96 \pm 0.19$ & - \\
\hline & & Methanol & $2.01 \pm 0.29$ & - & $1.70 \pm 0.77$ \\
\hline \multirow[t]{12}{*}{ Panjang Island } & S cinereum & n-hexane & - & - & - \\
\hline & & Ethyl acetate & $3.65 \pm 1.22$ & $6.63 \pm 1.02$ & $4.98 \pm 0.52$ \\
\hline & & Methanol & - & $2.45 \pm 0.12$ & $2.03 \pm 0.27$ \\
\hline & S polycystum & n-hexane & - & - & - \\
\hline & & Ethyl acetate & $4.13 \pm 0.24$ & $5.32 \pm 0.69$ & $6.22 \pm 0.97$ \\
\hline & & Methanol & $2.27 \pm 0.41$ & $3.03 \pm 0.28$ & $4.64 \pm 0.96$ \\
\hline & S crassifolium & n-hexane & - & - & - \\
\hline & & Ethyl acetate & $5.30 \pm 0.38$ & $5.98 \pm 0.47$ & $4.17 \pm 0.31$ \\
\hline & & Methanol & $3.25 \pm 0.01$ & - & $2.00 \pm 0.29$ \\
\hline & S duplicatum & n-hexane & $4.23 \pm 0.20$ & - & $4.52 \pm 0.49$ \\
\hline & & Ethyl acetate & $5.96 \pm 0.35$ & $4.98 \pm 0.44$ & $6.52 \pm 1.67$ \\
\hline & & Methanol & $3.25 \pm 0.01$ & - & $2.00 \pm 0.29$ \\
\hline \multirow[t]{9}{*}{ Bandengan } & S plagyophyllum & n-hexane & - & - & - \\
\hline & & Ethyl acetat & $4.62 \pm 0.15$ & $5.02 \pm 1.20$ & $5.23 \pm 1.21$ \\
\hline & & Methanol & $2.62 \pm 0.11$ & - & $2.24 \pm 0.84$ \\
\hline & S echinocarpum & n-hexane & - & - & - \\
\hline & & Ethyl acetate & $6.28 \pm 0.04$ & $4.03 \pm 0.88$ & $4.90 \pm 0.70$ \\
\hline & & Methanol & $1.91 \pm 0.20$ & $2.82 \pm 1.08$ & $3.06 \pm 0.71$ \\
\hline & S cinereum & n-hexane & - & - & - \\
\hline & & Ethyl acetate & $5.82 \pm 0.95$ & $5.66 \pm 0.98$ & $5.35 \pm 1.07$ \\
\hline & & Methanol & - & - & $3.88 \pm 0.34$ \\
\hline \multirow[t]{9}{*}{ Ujung piring } & S binder & n-hexane & - & - & - \\
\hline & & Ethyl acetate & - & - & $12.65 \pm 0.23$ \\
\hline & & Methanol & - & - & $11.33 \pm 0.44$ \\
\hline & S polycystum & n-hexane & - & - & - \\
\hline & & Ethyl acetate & - & - & $4.57 \pm 0.16$ \\
\hline & & Methanol & - & - & $4.35 \pm 0.42$ \\
\hline & S duplicatum & n-hexane & - & - & - \\
\hline & & Ethyl acetate & - & - & - \\
\hline & & Methanol & - & - & - \\
\hline \multirow[t]{3}{*}{ Bondo } & S binder & n-hexane & - & - & - \\
\hline & & Ethyl acetate & - & - & $5.16 \pm 0.13$ \\
\hline & & Methanol & - & - & - \\
\hline
\end{tabular}

Information: data are the average \pm standard deviation of bactericidal activity zone (mm)

Table 2. Result of Cluster Analysis Diameter Transparent Zone which has Bactericidal Activity and Large Spectrum

\begin{tabular}{|c|c|c|c|c|c|c|}
\hline \multicolumn{4}{|c|}{ Variable } & \multirow{2}{*}{$\begin{array}{c}\text { Staphylococcus } \\
\text { aureus }\end{array}$} & \multirow{2}{*}{$\begin{array}{c}\text { Escherichia } \\
\text { coli }\end{array}$} & \multirow{2}{*}{$\begin{array}{c}\text { Staphylococcus } \\
\text { epidermidis }\end{array}$} \\
\hline Cluster & Station & Species & Solvent & & & \\
\hline \multirow[t]{3}{*}{ Cluster 1} & Teluk Awur & S. duplicatum & Ethyl acetate & $3.62 \pm 0.05$ & $4.22 \pm 1.23$ & $6.81 \pm 1.46$ \\
\hline & Panjang Island & S. crassifolium & Ethyl acetate & $5.30 \pm 0.38$ & $5.98 \pm 0.47$ & $4.17 \pm 0.31$ \\
\hline & Bandengan & S. cinereum & Ethyl acetate & $5.82 \pm 0.95$ & $5.66 \pm 0.98$ & $5.35 \pm 1.07$ \\
\hline \multirow[t]{3}{*}{ Cluster 2} & Panjang Island & S. polycystum & Ethyl acetate & $4.13 \pm 0.24$ & $5.32 \pm 0.69$ & $6.22 \pm 0.97$ \\
\hline & Panjang Island & S. duplicatum & Ethyl acetate & $5.96 \pm 0.35$ & $4.98 \pm 0.44$ & $6.52 \pm 1.67$ \\
\hline & Bandengan & S plagyophyllum & Ethyl acetate & $4.62 \pm 0.15$ & $5.02 \pm 1.20$ & $5.23 \pm 1.21$ \\
\hline Cluster 3 & Panjang Island & S. cinereum & Ethyl acetate & $3.65 \pm 1.22$ & $6.63 \pm 1.02$ & $4.98 \pm 0.52$ \\
\hline
\end{tabular}




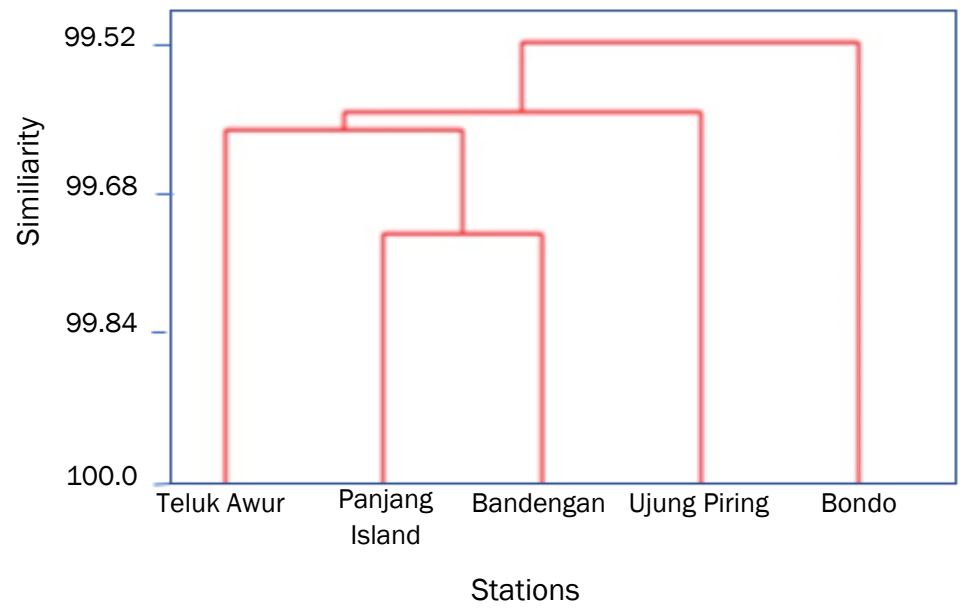

Figure 2. Cluster Analysis of Water Quality of All Stations

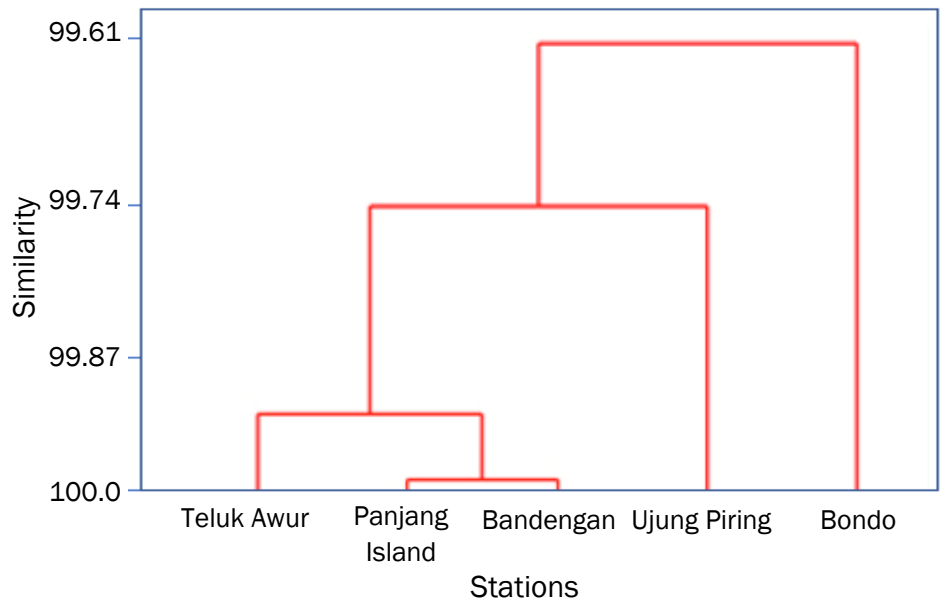

Figure 3. Cluster Analysis of Diameter Transparent Zone of Sargassum Extract Activity of All Stations

Extract with bactericidal activity in large spectrum then being classified into 3 classes (Similarity class 1,2 and 3 are $72.33 \%$; 76.80\%; dan 58.50\%). Class 1 has the best activity than class 2 and 3 . Class 1 consists of S. duplicatum from Teluk Awur with the average bioactivity 5.37 $\mathrm{mm}$; S. crassifolium from Panjang Island with the average of bioactivity $5.35 \mathrm{~mm}$ and $\mathrm{S}$. cinereum from Bandengan with the average of bioactivity 5.32 $\mathrm{mm}$ (Table 1).

If species abundance in each station is linked, S. duplicatum from Teluk Awur has highest abundance, which is 504 ind. $200 \mathrm{~m}^{2}$, S. crassifolium from Panjang Island has highest abundance of 337 ind. $200 \mathrm{~m}^{-2}$, and S. cinereum from Bandengan has highest abundance of 329 ind. $200 \mathrm{~m}^{2}$. Sargassum extract with the best activity has a linkage with abundance and linier positive relationship. Thus, Sargassum has the best activity and the best abundance (dominant) in its ecosystem. It is assumed that active compounds which are isolated have potency as antimicrobial that has been functioned by Sargassum and ecologically is for natural survival (Table 2).

\section{Conclusion}

The abundant and antimicrobial bioactive compound has linkages and assumed as the primary metabolite product of Sargassum. Water quality parameters affects the abundance and biochemical content of Sargassum.

\section{Acknowledgment}

Thank you to Direktorat Riset dan Pengabdian Masyarakat, Directorate General of Strengthening Research and Development. Ministry of Research Technology and Higher Education of Republic of Indonesia for providing research funds. 


\section{References}

Bhaigyabati, T., Kirithika, T., Shiny, K. \& Usha, K. 2011. Phytochemical Screening and Antioxidant Activity of Various Extracts of Sargassum muticum. Int. J. Pharm. Res. Dev. $3(10): 25-30$

Dahuri, R., Rais, J., Ginting, S.P. \& Sitepu, M.I. 1996. Pengelolaan Sumber Daya Wilayah Pesisir dan Laut Secara Terpadu, Jakarta, PT. Pradya Paramita. 305 pp.

English, S.S., Wilkinson, C.C. \& Baker, V.V. 1997. Survei Manual for Tropical Marine Resources. Townsville: Australian Institute of Marine Science.

Hardouin, K. Burlot, A.S., Umami, A., Tanniou, A., Stiger-Pouvreau, V., Widowati, I., Bedoux, G. \& Bourgougnon, N., 2013. Biochemical and antiviral activities of enzymatic hydrolysates from different invasive French seaweeds. J. Appl. Phycol. 26(2):1029-1042. doi: https://doi.org/10.1007/s10811-013-0201-6

Manivannan, K., Devi, G.K., Anantharaman, P. \& Balasubramanian, T. 2011. Antimicrobial Potential of Selected Brown Seaweeds from Vedalai Coastal Waters, Gulf of Mannar. Asian Pac. J. Trop. Biomed. 1(2): 114-120. doi: 10. 1016/S2221-1691(11)60007-5

Kanjana, K., Radtanatip, T., Asuvapongpatana, S., Withyachumnarnkul, B. \& Wongprasert, K., 2011. Solvent Extracts of The Red Seaweed Gracilaria fisheri Prevent Vibrio harveyi Infections in The Black Tiger Shrimp Penaeus monodon. Fish Shellfish Immunol. 30(1):389396. doi: 10.1016/j.fsi.2010.11.016

Khaled, N., Hiba, M. \& Asma, C. 2012. Antioxidant and Antifungal Activities of Padina pavonica and Sargassum vulgare from the Lebanese Mediterranean Coast. Adv Environmen. Biol. $6(1): 42-8$.

Kang, J.Y., Khan, M.N.A., Park, N.H., Cho, J.Y., Lee, M.C., Fujii, H. \& Hong, Y.K. 2008. Antipyretic, Analgesic, and Anti-inflammatory Activities of the Seaweed Sargassum fulvellum and Sargassum thunbergii in Mice. J. Ethnopharmacol. 116(1):187-190. doi: 10.1016/j.jep.2007.10.032

Lalitha, M.K. 2004. Manual on Antimicrobial Susceptibility Testing. Performance Standards for Antimicrobial Testing: Twelfth Informational Supplement. 56238:454-456.
Lobban, C.S. \& Paul, J.H. 1997. Seaweeed Ecology and Physiology. Cambridge University Press.

Zaragozá, M. C., López, D., P. Sáiz, M., Poquet, M., Pérez, J., Puig-Parellada, P., P., Marmol, F., Simonetti, P., Gardana, C. \& Lerat, Y. 2008. Toxicity and antioxidant activity in vitro and in vivo of two Fucus vesiculosus extracts. J. Agric. Food Chem. 56: 7773-7780. doi: 10.1021/ jf8007053.

Li, C, Li, X, You, L, Fu, X. \& Liu, R.H., 2017. Fractionation, Preliminary Structural Characterization and Bioactivities of Polysaccharides from Sargassum pallidum. Carbohydrate Polymers, 155:261-270. doi: 10.1016/j.carbpol.2016.08.075.

Nianjun, X., Fan, X., Yan, X. \& Tseng, K.C. 2004. Screening Marine Algae From China For Their Antitumor Activities. J. Appl. Phycol. 16:451456. doi: https://doi.org/10.1007/s10811004-5508-x

Pelczar, M.J. \& Chan, E.C.S., 2005. Dasar-Dasar Mikrobiologi 2. Hadioetomo, R.S., Imas, T., Tjitrosomo, S.S., Angka, S.L. (Translators). UI Press. Jakarta. Translated from Elements of Microbiology.

Plouguerné, E., Ioannou, E., Georgantea, P., Vagias, C., Roussis, V., Hellio, C., Kraffe, E. \& StigerPouvreau, V. 2010. Anti-microfouling Activity of Lipidic Metabolites from The Invasive Brown Alga Sargassum muticum (Yendo) Fensholt. Mar. Biotech. 12(1):52-61. doi: 10.1007/ s10126-009-9199-9

Puspita, M., Deniel, M., Widowati, I., Radjasa, O.K., Douzenel, P., Bedoux, G. \& Bourgougnon, N., 2012. Antioxidant and Antibacterial Activity of Solid-Liquid and Enzyme-Assisted Extraction of Phenolic Compound from Three Species of Tropical Sargassum. J. Phys. Conf. Ser. 365:11001.

Tanniou, A., Vandanjon, L., Incera, M., Leon, E.S., Husa, V., Le Grand, J., Nicolas, J.L., Poupart, N., Kervarec, N., Engelen, A. \& Walsh, R., 2014. Assessment of the spatial variability of phenolic contents and associated bioactivities in the invasive alga Sargassum muticum sampled along its European range from Norway to Portugal. J. Appl. Phycol. 26(2):1215-1230. doi: 10.1007/s10811-013-0198-x

Widowati, I., Puspita, M., Stiger-Pouvreau, V. \& Bourgougnon, N., 2014. Potentiality of Using Spreading Sargassum Species from Indonesia 
as an Interesting Source of Antibacterial and Radical Scavenging Compounds: A Preliminary Study. Int. J. Mar. Aquatic Res. Conservation and Co-existence. 1(1):63-67.

Rastian, Z., Mehranian, M., Farzaneh, V. \& Kohzad S. 2007. Antioxidant Activity of Extract From a
Brown Alga, Sargassum boveanum. Africa J. Biotechnol. 6(24):2740-2745 